\title{
Degradation of Urban Green Spaces in Lagos, Nigeria: Evidence from Satellite and Demographic Data
}

\author{
Yaw A. Twumasi ${ }^{*}$, Edmund C. Merem ${ }^{2}$, John B. Namwamba', Olipa S. Mwakimi ${ }^{3}$, \\ Tomas Ayala-Silva ${ }^{4}$, Kamran Abdollahi' ${ }^{1}$, Ronald Okwemba ${ }^{1}$, Onyumbe E. Ben Lukongo ${ }^{5}$, \\ Caroline 0. Akinrinwoye ${ }^{1}$, Joshua Tate ${ }^{1}$, Kellyn LaCour-Conant ${ }^{1}$
}

\author{
${ }^{1}$ Department of Urban Forestry and Natural Resources, Southern University and A \& M College, 102 Fisher Hall, Baton Rouge, \\ Louisiana, USA \\ ${ }^{2}$ Department of Urban and Regional Planning, Jackson State University, 101 Capitol Center, Jackson, Mississippi, USA \\ ${ }^{3}$ Institute of Resource Assessment, University of Dares Salam, Dares Salam, Tanzania \\ ${ }^{4}$ USDA-ARS Tropical Agriculture Research Station, Suite 201, Mayaguez, Puerto Rico \\ ${ }^{5}$ Department of Public Policy, Southern University and A \& M College, Nelson Mandela College of Government and Social \\ Sciences, Baton Rouge, Louisiana, USA \\ Email: *yaw.twumasi@subr.edu, ‘yaw.twumasi@gmail.com
}

How to cite this paper: Twumasi, Y.A., Merem, E.C., Namwamba, J.B., Mwakimi, O.S., Ayala-Silva, T., Abdollahi, K., Okwemba, R., Lukongo, O.E.B., Akinrinwoye, C.O., Tate, J. and LaCour-Conant, K. (2020) Degradation of Urban Green Spaces in Lagos, Nigeria: Evidence from Satellite and Demographic Data. Advances in Remote Sensing, 9, 33-52.

https://doi.org/10.4236/ars.202091003

Received: January 19, 2020

Accepted: March 28, 2020

Published: March 31, 2020

Copyright (c) 2020 by author(s) and Scientific Research Publishing Inc. This work is licensed under the Creative Commons Attribution International License (CC BY 4.0).

http://creativecommons.org/licenses/by/4.0/ c) (i) Open Access

\begin{abstract}
The study aimed to assess the potential of using Remote Sensing (RS) data to evaluate the changes of urban green spaces in Lagos, Nigeria. Landsat Thematic Mapper and Landsat 8 (Operational Land Imager) data pair of May 4, 1986, December 12, 2002 and January 1, 2019 covering Lagos Government Authority (LGA) were used for this study. Supervised image classification technique using Maximum Likelihood Classifier (MLC) was used to create base map which was then used for ground truthing. Random Forest (RF) classification technique using RF classifier was utilized in this study to generate the final land use land cover map. RF is an ensemble learning method for classification that operates by constructing a multitude of decision trees at training time and outputting the class that is the mode of the classes (classification). Lagos census population data was also used in this study to model population projection. Extrapolation of the model was used to predict data for the years, 2020 and 2040. Results of the study revealed a reduction of urban green spaces due to agriculture and settlement. While the remote mapping revealed the gradual dispersion of ecosystem degradation indicators spread across the state, there exists clusters of areas vulnerable to environmental hazards across Lagos. To mitigate these risks, the paper offered recommendations ranging from the need for effective policy to green planning education for city managers, developers and risk assessment. These measures
\end{abstract}


will go a long way in helping sustainability and management of land resources in Lagos.

\section{Keywords}

Remote Sensing, Urban Green Spaces, Population Projection, Lagos

\section{Introduction}

Urban green spaces such as parks and sports fields as well as woods and natural meadows, wetlands and other ecosystems provide several benefits. They serve as filters of pollutants and dust from the air, facilitate physical activity and relaxation, provide shade and lower temperatures in urban areas, and they reduce erosion of soil into the waterways [1]. Trees produce oxygen, and help filter out harmful air pollution, including airborne particulate matter [2]. Despite these benefits, urban green spaces in recent years have come under intense pressure due to increase in population growth. Increasing population could be attributed to the social and economic benefits associated with urban centers compared to rural areas [3]. Rapid urban growth, however, has major social and economic consequences including congestion and environmental degradation of green spaces. Published research by authors on environmental impacts of urban expansion shows pressure on undeveloped green spaces [3] [4] [5] [6]. Similarly, early work of Merem and Twumasi [7] on urban growth management in Central Mississippi region which is home to over half a million people revealed decline of the area's agricultural land resources due to urban development. Indeed, the impacts of land use change associated with the development and urbanization have well been documented [8] [9] [10]. Early work of Twumasi et al., [11] and [12] and Manu et al., [13] used satellite data to map urban green spaces in Accra, Ghana; Bamako, Mali and Niamey, Niger. Results of these studies showed that the decline in green spaces in these cities was associated with urban development and urbanization. In Lagos, Nigeria, anthropogenic activities that drive changes in land use and cover include urban development which is associated with urbanization and agricultural practices. Such activities have exerted much pressure through intense use of green spaces for residential and industrial purposes [14] [15] [16]. Several studies have employed remote sensing data to assess the integrity of green spaces and ecosystem in Lagos [17] [18] [19] [20] [21]. However, none of these studies integrate remote sensing data with demographic analysis. This calls for the need to find appropriate method to aid in identifying spatio-temporal changes in urban green spaces in Lagos. Perhaps, the most important element in these efforts is the need to integrate satellite data with demographic analysis to assess the status and trend of the urban green spaces. The primary objectives of this study were to couple remote sensing data with demographic data to evaluate the changes of urban green spaces in Lagos, Nigeria to 
enable planners and policymakers contribute to improved land administration and enhance their competence in decision-making (Figure 1).

\section{Methodology}

\subsection{The Study Area}

Lagos state is situated in the South Western Nigeria within latitudes 6 degrees 23 ' $\mathrm{N}$ and Longitudes 2 degrees and 3 degrees 42 E. As shown in Figure 2 and Figure 3, the state is bounded from the North and East by Ogun State, in the West by the Republic of Benin and the South by the Atlantic Ocean. The total land mass of the state stretches over 3345 kilometers. Like most African cities, Lagos, Nigeria, is experiencing a fast-sustained urban expansion (Figure 3). According to 2019 World Population Review and Statistical Data, Lagos population is increasing at a startling rate. The current 2019 population is estimated at $13,903,620$. In 1950, the population of Lagos was 325,218 . This has grown by $1,664,414$ since 2015 , which represents a $3.24 \%$ annual change. While the state appears physically smaller, it is ranked as the most highly populated state in the country with an estimated population of about 14 million inhabitants representing $10 \%$ of the total population of Nigeria [22].

\subsection{Data Acquisition}

This paper used satellite remote sensing and census-population data for the analysis.

\subsection{Image Data Acquisition and Processing}

Landsat Thematic Mapper and Landsat 8 (Operational Land Imager) images listed in Table 1 covering Lagos, Nigeria were acquired from the United States Geological Survey Earth Explorer free Online Data Services for land use land cover change classifications analysis [24]. The images were acquired with minimum cloud cover $(<10 \%)$. The footprint of the Landsat data is shown in Figure 4.

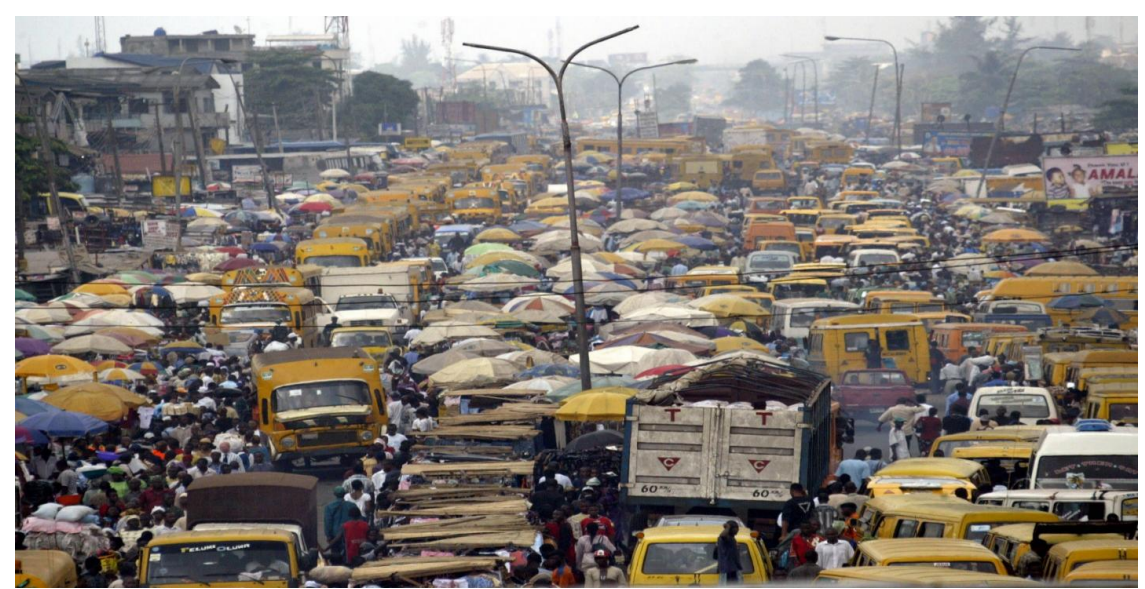

Figure 1. A heavily crowded street in Lagos, Nigeria. Curtesy: Reddit [16]. 


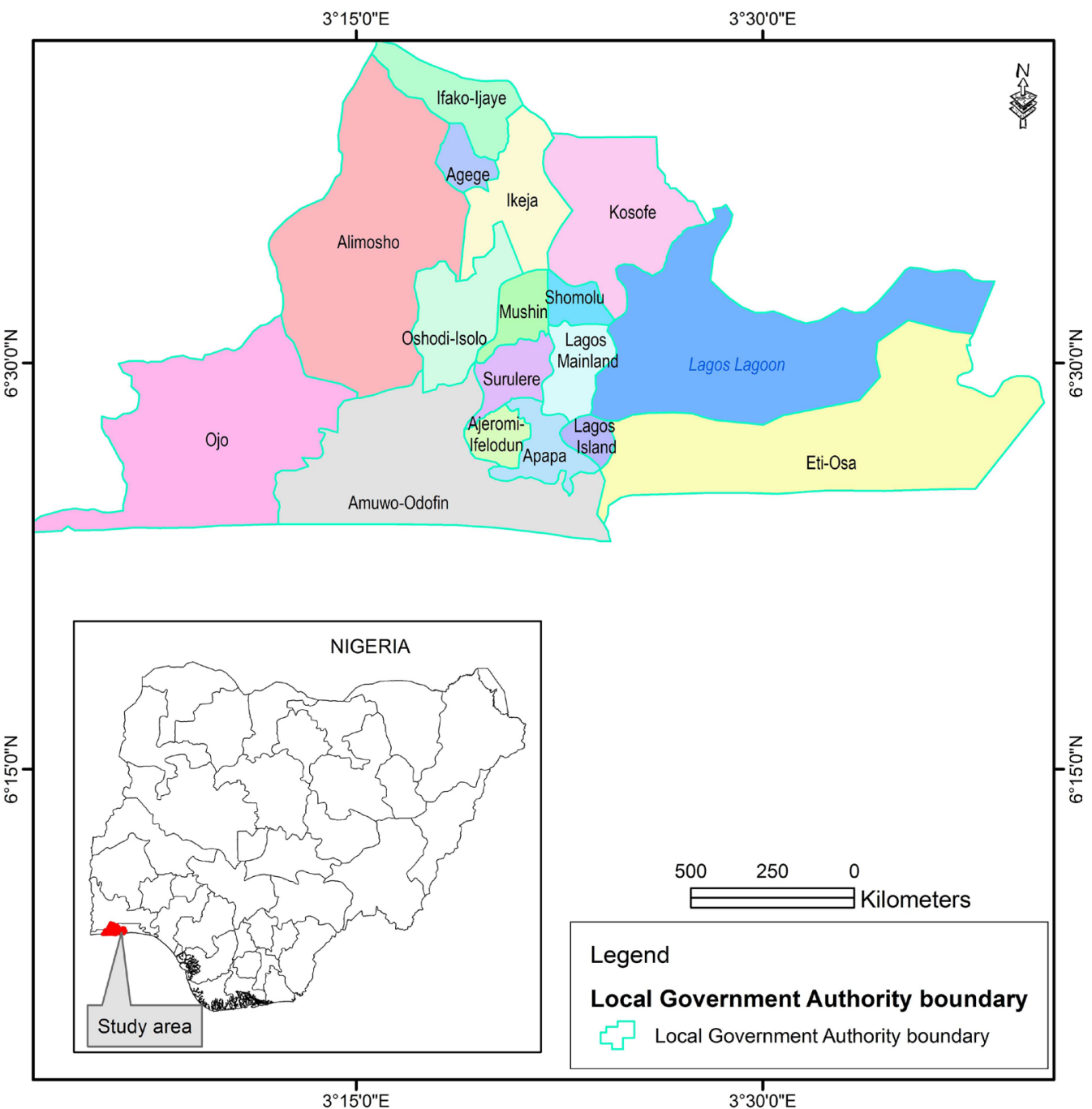

Figure. 2. Study area. The map shows Lagos Metropolitan Areas. Insert shows the position of Lagos in Nigeria.

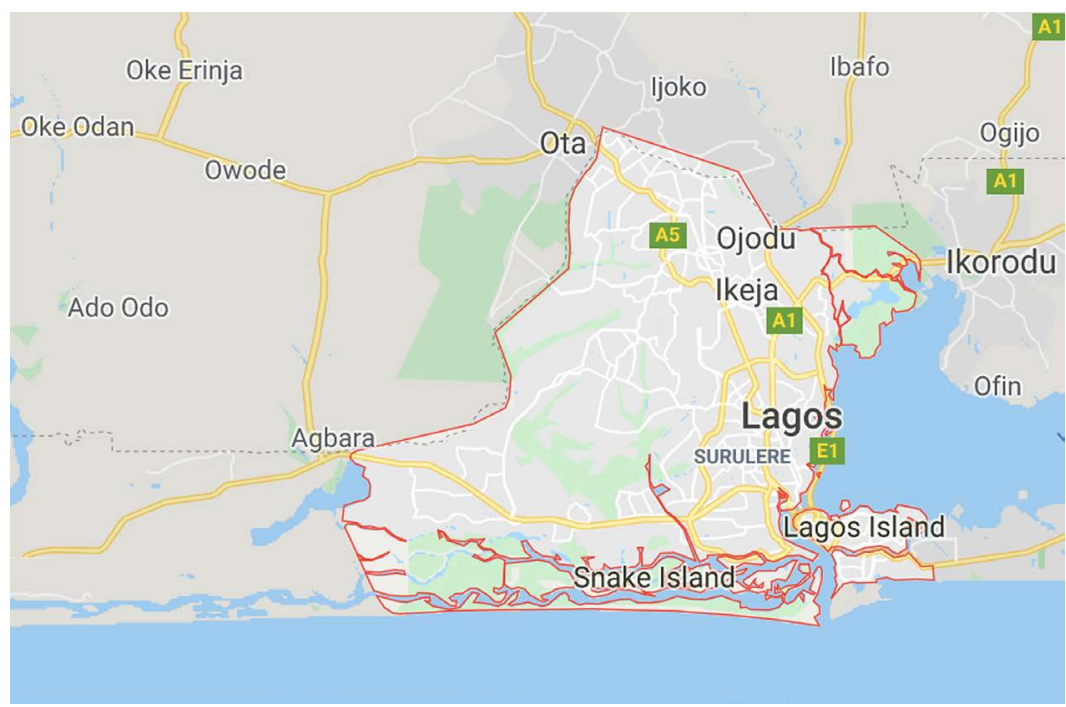

Figure 3. Map of Metropolitan Lagos from Google [23]. 
Table 1. Landsat images used in the mapping land use land cover of LGA.

\begin{tabular}{ccccc}
\hline Reference year & Sensor & Resolution & WRS: P/R & Date of Acquisition \\
\hline 2019 & Landsat 8 & $30 \mathrm{~m}$ & $191 / 055$ & $2019 / 01 / 01$ \\
2002 & Landsat TM & $30 \mathrm{~m}$ & $191 / 055$ & $2002 / 12 / 28$ \\
1986 & Landsat TM & $30 \mathrm{~m}$ & $191 / 055$ & $1986 / 04 / 12$ \\
\hline
\end{tabular}

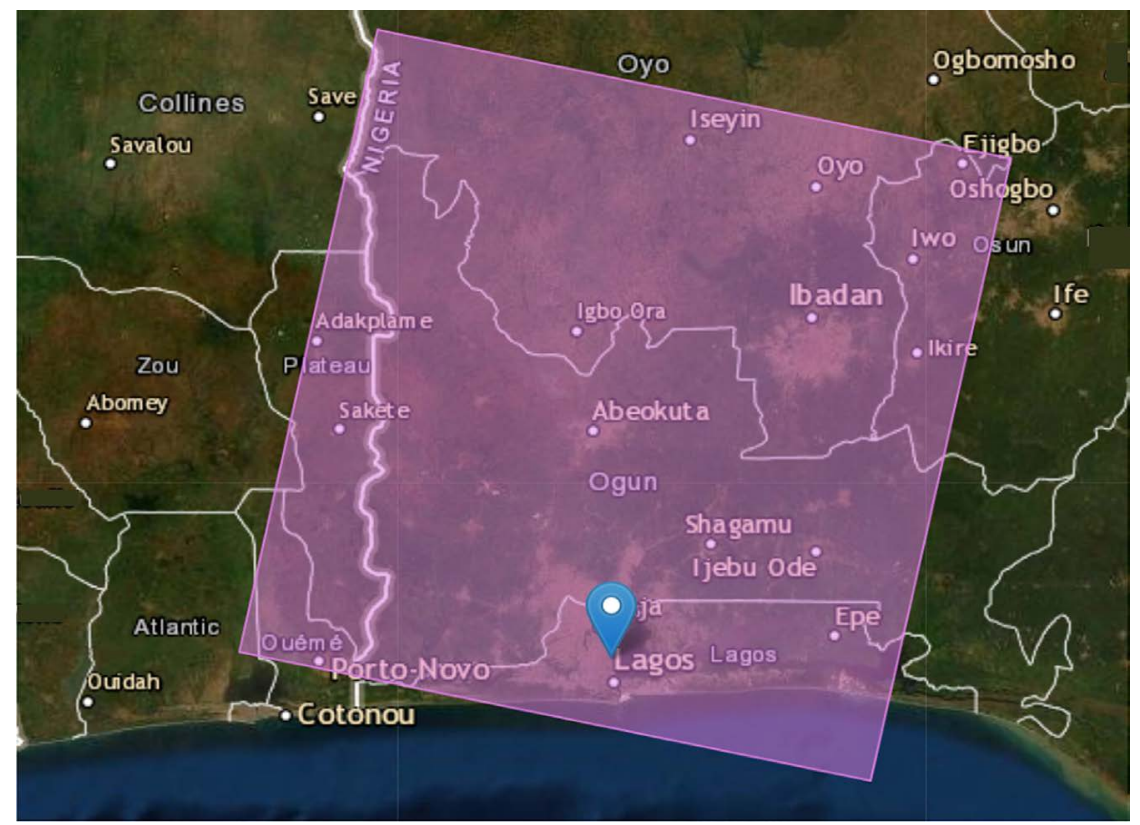

Figure 4. Footprint of Landsat imagery in the study area shown in dark purple color box [24].

\subsection{Image Processing}

To process the images, three tasks were performed. These include: Image preprocessing, rectification and image enhancement.

\subsubsection{Image Pre-Processing}

In image Image pre-processing, both visual and digital image processing were done, and prior to image processing, images were imported into ERDAS Imagine Image Processing Software for further processing. Since the images were in single bands, layer stack technique was performed to group the bands together. The stacked images were further exported to ArcGIS 10.6 software. Lagos Government Authority (LGA) shapefile was used to extract from the full scenes to subset the area of interest which is the Lagos Government Authority (LGA).

\subsubsection{Image Rectifications}

Image rectifications were performed in order to correct the data for distortion which may have been developed from the image acquisition process using the Impact toolbox developed by the European Union Joint Research Centre. To ensure accurate identification of temporal changes and geometric compatibility with other sources of information, the images were geocoded to the coordinate 
and mapping system of the national topographic maps. All the images were projected to the Universal Traverse Mercator (UTM) coordinates zone 31 North. The spheroid and datum was also referenced to WSG84.

\subsubsection{Image Enhancement}

Image enhancement was done in order to reinforce the visual interpretability of images, a colour composite (Landsat TM bands 4, 5, and 3) was prepared and its contrast was stretched using a standard deviation to further enhance visual interpretability of linear features like Rivers, and land use features like agricultural land, forests etc. Aside using Erdas Imagine Image Processing software to perform the layer stack of the images, all image processing was carried out using ArcGIS software and Impact toolbox.

\subsection{Preliminary Image Classification and Ground Truthing}

Supervised image classification using Maximum Likelihood Classifier (MLC) was used to create base map which was then used for ground truthing. The maximum likelihood classifier was selected since, unlike other classifiers it considers the spectral variation within each category and the overlap cover the different classes. Accordingly, the land use and land cover was classified into eight classes, namely forest, bushland, and agriculture with scattered settlements, grassland, bare soil, wetland, water and Settlements (Urban Area) (Table 2).

\subsection{Final Image Classification}

Random Forest (RF) classification using RF classifier was utilized in this study to generate the final land use land cover map. RF is an esemble learning method for

Table 2. Detailed description of land use land cover Lagos Government Authority.

\begin{tabular}{|c|c|}
\hline $\begin{array}{l}\text { Land Use Land cover } \\
\text { (LAND COVER) Categories }\end{array}$ & Description \\
\hline Forest & $\begin{array}{l}\text { An area of land with at least } 0.5 \text { ha, with a minimum tree crown cover of } 10 \% \text { or with existing tree species planted } \\
\text { or natural having the potential of attaining more than } 10 \% \text { crown cover, and with trees which have the potential } \\
\text { or have reached a minimum height of } 3 \mathrm{~m} \text { at maturity in situ. It includes montane, lowland, mangrove and } \\
\text { plantation forests, woodlands and thickets. }\end{array}$ \\
\hline Bushland & $\begin{array}{l}\text { Bushland is fundamentally defined as being predominantly comprised of plants that are multi-stemmed from a } \\
\text { single root base. It includes dense and open bushland }\end{array}$ \\
\hline Grassland & $\begin{array}{l}\text { For the most part, grassland occurs in combination with either a limited wooded or bushed component, or with } \\
\text { scattered subsistence cultivation }\end{array}$ \\
\hline $\begin{array}{l}\text { Agriculture with } \\
\text { Scattered Settlements }\end{array}$ & $\begin{array}{l}\text { Land actively used to grow agricultural crops including agro forestry systems, wooded crops, herbaceous crops } \\
\text { and grain crops }\end{array}$ \\
\hline Bare Soil & The land which includes bare land and coastal sands \\
\hline Settlements/Built up Area & Built up areas especially urban areas \\
\hline Water & Includes inland water and ocean \\
\hline Wetland & $\begin{array}{l}\text { Land which is water logged seasonally. May be wooded such as marshland, perennially flooded plains and swampy } \\
\text { areas }\end{array}$ \\
\hline
\end{tabular}


classification that operates by construction of a multitude of decision trees at training time and outputting the class which is the mode of the classes (classification). The advantages of RF is that it is not sensitive to over-fitting; good at dealing with outliers in training data, and it is able to calculate useful information about errors, variable importance, and data outliers [25]. This information can be used to evaluate the performance of the model and make changes to the training data if necessary.

\subsection{Preparation of Land Cover and Land Use Maps}

Classified images were recorded to the respective classes. Classified images were then filtered using a majority-neighbourhood filter in order to eliminate patches smaller than a specified value and replace them with the value that is most common among the neighboring pixels.

\subsection{Change Detection and Assessment of the Rate of Change}

In this study Post classification, comparison was used to quantify the extent land use, land cover changes over a 30 year period (1986, 2002 and 2019). The advantage of post classification comparison is that it bypasses the difficulties associated with the analysis of the images that are acquired at different times of the year, or by different sensors and results in high change detection accuracy [26]. Estimation for the rate of change for different land use land cover was computed based on the following formulae.

$$
\begin{aligned}
& \% \text { Cover change }=\frac{\text { Area }_{i \text { year } x}-\text { Area }_{i \text { year } x+1}}{\sum_{i=1}^{n} \text { Area }_{i \text { year } x}} \times 100 \\
& \text { Annual rate of change }=\frac{\text { Area }_{i \text { year } x}-\text { Area }_{i \text { year } x+1}}{t_{\text {years }}}
\end{aligned}
$$

where: Area $_{i \text { year } x}=$ area of cover $i$ at the first date,

Area $_{i \text { year } x+1}=$ area of cover $i$ at the second date,

$\sum_{i=1}^{n}$ Area $_{i_{\text {year } x}}=$ total cover area at the first and

$t_{\text {years }}=$ period in years between the first and second scene acquisition date.

\subsection{Census-Population Data Acquisition and Processing}

Population data for this study was obtained from World Statistical Data website [22]. The Lagos population data was modeled using Microsoft Excel's statistical data analysis tool. Table 3 represents the data used for modeling. Also, linear time series slopes were analyzed to model population projection. Extrapolation of the model was used to predict data for the years, 2020 and 2040.

\section{Results and Discussion}

Table 3 and Figure 5 show the results of the classification for 1986, 2002 and 2019 Landsat images. From Table 4, land area under water declined from the 


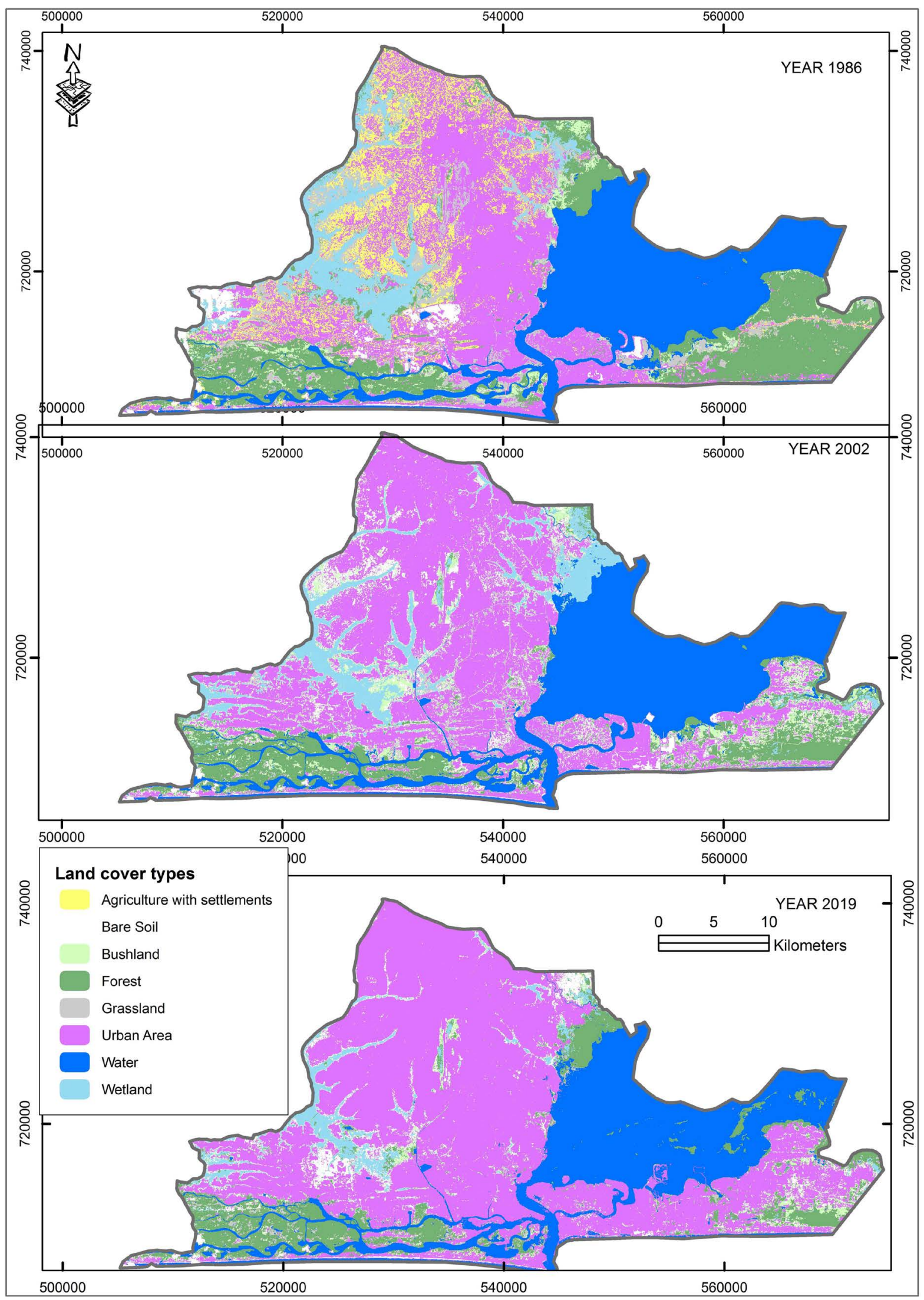

Figure 5. Land cover maps of LGA 1986-2019. 
Table 3. 1950-2019 Lagos population data for modeling, based on 1950,1960, 1970, 1980, 1990, 2000, 2010 and 2019 data.

\begin{tabular}{cc}
\hline & Population versus Year Analysis \\
\hline Year & Population \\
\hline 1950 & 325,000 \\
1960 & 762,000 \\
1970 & $1,414,000$ \\
1980 & $2,572,000$ \\
1990 & $4,764,000$ \\
2000 & $7,281,000$ \\
2010 & $10,441,000$ \\
2019 & $13,904,000$ \\
\hline
\end{tabular}

Table 4. \% Change of land cover area between 1986 and 2019 in the LGA.

\begin{tabular}{lcccccc}
\hline & & \multicolumn{3}{c}{ COVERAGE } & \multicolumn{2}{c}{ Land Cover Change } \\
\cline { 3 - 7 } & \multirow{2}{*}{ Land Use/Cover Types } & 1986 & 2002 & $\mathbf{2 0 1 9}$ & \% Change \\
\cline { 3 - 7 } & $\mathrm{Ha}$ & $\mathrm{Ha}$ & $\mathrm{Ha}$ & $1986-2002$ & $2002-2019$ \\
\hline \multirow{2}{*}{1} & Agriculture with settlements & 12,208 & 7959 & 5549 & -34.81 & -30.28 \\
2 & Bare Soil & 2324 & 649 & 220 & -72.07 & -66.10 \\
3 & Bushland & 2716 & 6505 & 3161 & 139.50 & -51.40 \\
4 & Forest & 21,246 & 12,231 & 11,509 & -42.43 & -5.90 \\
5 & Grassland & 9359 & 5150 & 1870 & -44.97 & -63.68 \\
6 & Urban Area & 33,469 & 47,575 & 64,245 & 42.14 & 35.03 \\
7 & Water & 29,005 & 29,466 & 27,662 & 1.58 & -6.12 \\
8 & Wetland & 7916 & 8708 & 4026 & 10.01 & -53.76 \\
\hline
\end{tabular}

initial estimate of 29,466 hectares (ha) in 2002 to 27,662 in 2019. This represents an overall decrease of 6.12 percent. Urban area experienced significant expansion for the whole area from 1986 to 2019, while the size of area covered by vegetation, which include coastal mangrove (wetland), forest, bushland and grassland areas experienced a significant decline from 1986 to 2019 (Figure 5 and Table 4). Overall, the shrinking of the water resources (Water bodies and Wetlands) in the LGA (Tables 4-6) signifies worrying situation in LGA hence, needs serious intervention to rescue the situation.

Over the past two decades, the landscape of LGA has witnessed changes in its land use/cover (Figure 5, Table 4). The changes have been exhibited throughout the landscape.

\section{Demographic Analysis}

Results of census-population data analysis are shown in Table 7 and Table 8. Table 7 was generated by linear regression of 1950, 1960, 1970, 1980, 1990, 2000, 
Table 5. Land cover change by cross tabulation for year 1986 and 2002.

\begin{tabular}{|c|c|c|c|c|c|c|c|c|c|c|}
\hline \multirow[b]{2}{*}{ Year 2002} & \multicolumn{10}{|c|}{ Year: 1986} \\
\hline & $\begin{array}{l}\text { Agriculture with } \\
\text { settlements }\end{array}$ & Bare Soil & Bushland & Forest & Grassland & $\begin{array}{l}\text { Urban } \\
\text { Area }\end{array}$ & Water & Wetland & TOTAL & $\begin{array}{c}\text { Gross gain } \\
\text { [Total-unchanged] }\end{array}$ \\
\hline $\begin{array}{l}\text { Agriculture with } \\
\text { settlements }\end{array}$ & 1494 & 126 & 97 & 1318 & 1468 & 2433 & 82 & 830 & 7848 & 6354 \\
\hline Bushland & 364 & 97 & 839 & 2389 & 1028 & 484 & 76 & 1184 & 6461 & 5622 \\
\hline Forest & 45 & 124 & 878 & 10,144 & 646 & 234 & 87 & 41 & 12,199 & 2055 \\
\hline Grassland & 427 & 91 & 71 & 1116 & 961 & 2118 & 121 & 245 & 5,149 & 4187 \\
\hline Urban Area & 9542 & 1518 & 111 & 2933 & 4043 & 27,811 & 484 & 1208 & 47,651 & 19,840 \\
\hline Wetland & 193 & 258 & 434 & 2521 & 802 & 134 & 32 & 4453 & 8826 & 4373 \\
\hline TOTAL & 12,080 & 2294 & 2708 & 21,260 & 9368 & 33,582 & 29,021 & 7961 & & \\
\hline Gross loss & 10,586 & 2222 & 1869 & 11,117 & 8407 & 5771 & 1006 & 3508 & & \\
\hline
\end{tabular}

Table 6. Land cover change by cross tabulation for year 2002 and 2019.

\begin{tabular}{|c|c|c|c|c|c|c|c|c|c|c|}
\hline \multirow[b]{2}{*}{ Year 2019} & \multicolumn{10}{|c|}{ Year: 2002} \\
\hline & $\begin{array}{l}\text { Agriculture with } \\
\text { settlements }\end{array}$ & Bare Soil & Bushland & Forest & Grassland & $\begin{array}{l}\text { Urban } \\
\text { Area }\end{array}$ & Water & Wetland & $\begin{array}{c}\text { TOTAL } \\
2019\end{array}$ & $\begin{array}{c}\text { Gross gain } \\
\text { [Total-unchanged] }\end{array}$ \\
\hline $\begin{array}{l}\text { Agriculture with } \\
\text { settlements }\end{array}$ & 1060 & 6 & 1077 & 640 & 273 & 876 & 30 & 1524 & 5485 & 4425 \\
\hline Bushland & 217 & 2 & 884 & 913 & 288 & 238 & 39 & 575 & 3155 & 2272 \\
\hline Forest & 158 & 11 & 869 & 7597 & 150 & 121 & 1010 & 1587 & 11,503 & 3905 \\
\hline Grassland & 41 & 0 & 397 & 566 & 559 & 39 & 184 & 89 & 1875 & 1316 \\
\hline Urban Area & 6352 & 386 & 2970 & 2265 & 3816 & 46,298 & 967 & 1164 & 64,217 & 17,919 \\
\hline Wetland & 13 & 0 & 182 & 52 & 11 & 13 & 7 & 3833 & 4111 & 278 \\
\hline TOTAL 2002 & 7853 & 713 & 6445 & 12,219 & 5155 & 47,646 & 29,416 & 8826 & & \\
\hline Gross loss & 6794 & 451 & 5561 & 4622 & 4596 & 1348 & 2237 & 4993 & & \\
\hline
\end{tabular}

Table 7. Regression statistics table.

\begin{tabular}{cc}
\hline \multicolumn{1}{c}{ Regression Statistics } \\
Multiple R & 0.956719 \\
R Square & 0.91531 \\
Adjusted R Square & 0.901195 \\
Standard Error & $1,560,157$ \\
Observations & 8 \\
\hline
\end{tabular}


Table 8. Regression model table, based on 1950, 1960, 1970, 1980, 1990, 2000, 2010 and 2019 data.

\begin{tabular}{ccccccccc}
\hline & Coefficients & Standard Error & $t$ Stat & P-value & Lower 95\% & Upper 95\% & Lower 95.0\% & Upper 95.0\% \\
\hline Intercept & $-3.8 \mathrm{E}+08$ & $48,184,663$ & -7.94467 & 0.000211 & $-5 \mathrm{E}+08$ & $-2.6 \mathrm{E}+08$ & $-5 \mathrm{E}+08$ & $-2.6 \mathrm{E}+08$ \\
Year & $195,475.3$ & $24,274.33$ & 8.052757 & 0.000196 & $136,078.1$ & $254,872.4$ & $136,078.1$ & $254,872.4$ \\
\hline
\end{tabular}

2010 and 2019 data. The model explains about $90 \%$ of the data's variation and is statistically significant, $\mathrm{p}<0.05$ (Table 8 ).

The trend of population using the linear model was compared to the actual population for the year range 1950-2019 and illustrated by Figure 6. As shown in Figure 6, the linear model's population projections from 2009 and beyond were lower than the corresponding actual populations. The model is presented in Figure 7 in an extrapolated form, illustrating clearly the increasing difference between the projected and actual populations. The red dots illustrate the actual data while the blue line represents the linear model projection the population. Also presented in Figure 7, are the model equation and its coefficient of correlation. Although it explains about $91 \%$ of the variation in the population data, its projection of 2019 population is approximately $12,000,000$, which is about 2 million below the actual figure. When the data was fitted to a polynomial second order model by Microsoft Excel data analysis tool kit, the predictions approximated to the actual data (Figure 8). The coefficient of correlation for this model is approximately $100 \%$. Hence, the model explains about $100 \%$ of the variation in the population data. Based on its strength, this model was adopted projection the population of the city beyond the year 2019 .

Extrapolation of the second order polynomial (quadratic) model was used to predict data for the years beyond 2020.

The population projections based on the second order polynomial model are presented in Table 9.

To model the change in population per year for the years, 1950, 1960, 1970, $1980,1990,2000,2010$ and 2019, the population changes between each consecutive pair of data were computed and the difference divided by the corresponding span of time for the change. The computation was carried out as follows. The population growth/year for a 10-year interval $T n$ and $T n+10$ was determined using the following formula.

$$
P / \text { year for interval }\left(T_{n+10}-T_{n}\right)=\left(P_{T n+10}-P_{T n}\right) / 10
$$

The following graph illustrates the rate of population change (number of people/year) per year versus time in years.

As illustrated in Figure 9, the rate of population growth is positive and can be represented by the linear model,

$$
y=5991.6 x-10000000
$$

where $y$ and $x$ represent the population change/year and time in years respectively. The computed data is presented in Table 10. In Table 10, the year $\mathrm{n}$ refers to the time interval, year n-10 to year n. For example, 1960, refers to the interval, 1950-1960. 


\section{Comparison of population trend (linear model) with actual population versus years.}

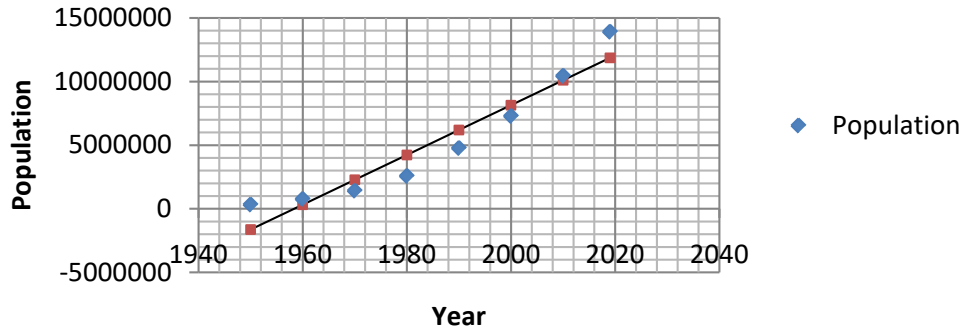

Figure 6. Comparison between actual population and predicted population using linear model, based on 1950, 1960, 1970, 1980, 1990, 2000, 2010 and 2019 data.

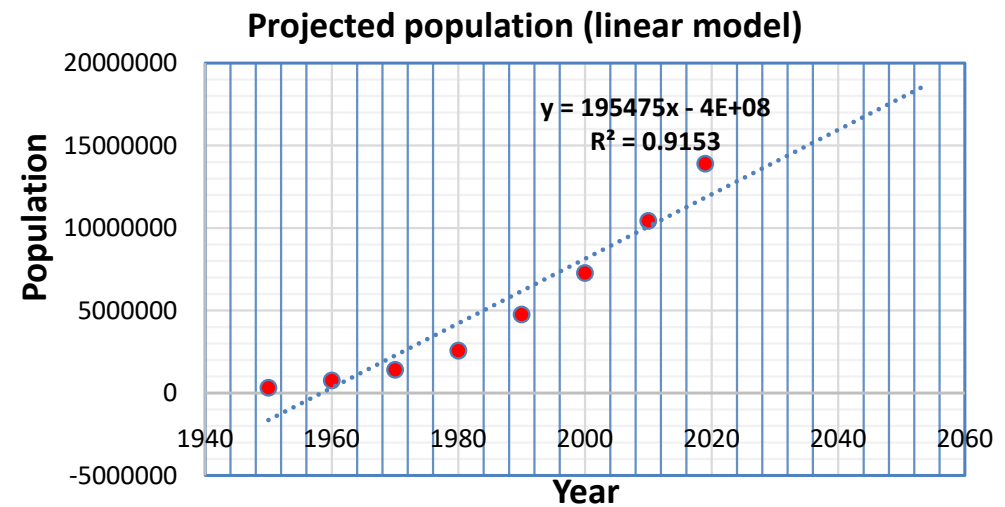

Figure 7. Projected population beyond 2020, using linear model for Lagos City Population versus year based on 1950, 1960, 1970, 1980, 1990, 2000, 2010 and 2019 data.

\section{Projected population of Lagos City versus year (quadratic model)}

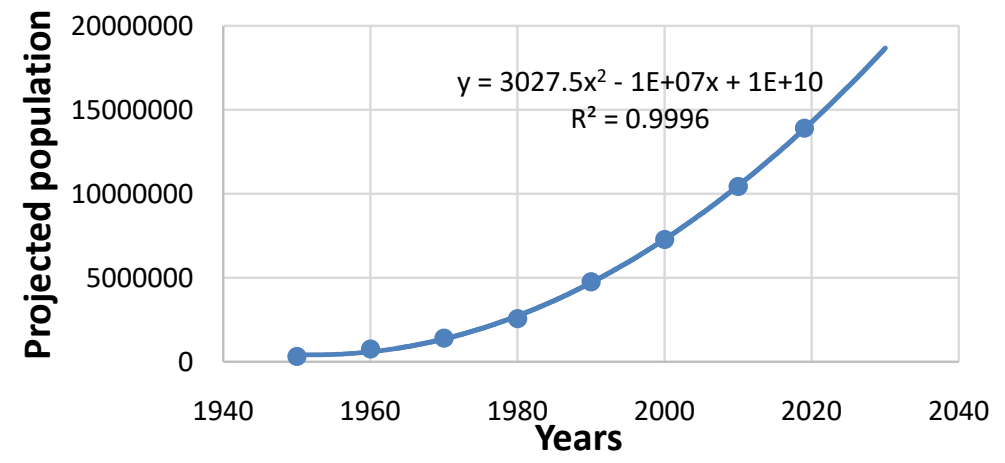

Figure 8. Projected population using a polynomial second order model for Lagos City Population versus year based on 1950, 1960, 1970, 1980, 1990, 2000, 2010 and 2019 data.

Table 9. Lagos City population projections based on the second order polynomial model.

\begin{tabular}{ll}
\hline Year & Projection \\
\hline 2025 & $17,000,000$ \\
2030 & $19,000,000$ \\
2035 & $22,000,000$
\end{tabular}


Table 10. Population change/year based on 1950, 1960, 1970, 1980, 1990, 2000, 2010 and 2019 data.

\begin{tabular}{cc}
\hline Year & Rate of population change (change/year) \\
\hline 1960 & 43,700 \\
1970 & 65,200 \\
1980 & 115,800 \\
1990 & 219,200 \\
2000 & 251,700 \\
2010 & 316,000 \\
2019 & 384,778 \\
\hline
\end{tabular}

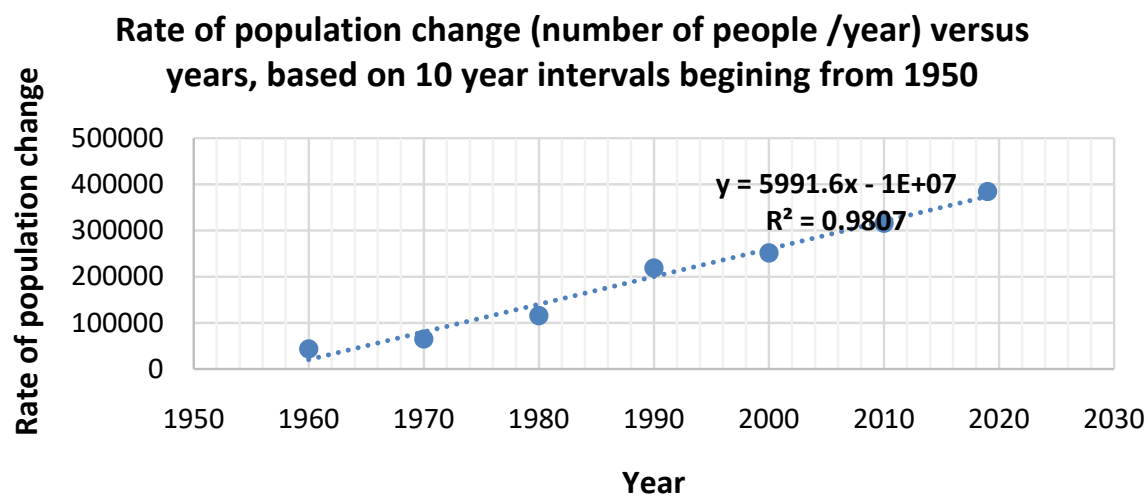

Figure 9. The rate of population change (number of people/year), based on 1950, 1960, 1970, 1980, 1990, 2000, 2010 and 2019 data, measured at 10 year intervals.

The lowest population growth/year occurred during the time span 1950-1960. It was determined using Equation (4) as follows.

$$
\dot{P}_{(1950-1960)}=(762000-325000 / 10)=43700 \text { per year , }
$$

where $\dot{P}_{(1950-1960)}$ is the corresponding rate of population change. The period with the highest population growth was found to be 1980-1990. The corresponding rate of population change was computed as follows.

$$
\dot{P}_{(2010-2019)}=(13904000-10441000 / 9)=384778
$$

The percentage change in population between a span of time is the ratio of the population change over a time interval in years, to preceding population, multiplied by $100 \%$. It was determined as follows.

$$
\text { Percentage change in population }=\left(\left(P_{t}-P_{t-10}\right) / P_{t-10}\right) * 100 \%
$$

where $P_{t}$ and $P_{t-10}$ represent the populations for the years $t$ and $t-10$ (10 years earlier than $\mathrm{t}$ ), respectively. The percentage changes in population for consecutive 10-year intervals, 1950-1960 and were computed using Equation (5) as follows.

$$
(762000-325000 / 325000) * 100 \%=134.46 \%
$$


The percentage change in population per consecutive 10 years for Lagos population was computed for the data for 1950-2019 and illustrated in Table 11.

Using curve fitting with Microsoft Excel, four possible models, exponential, polynomial (quadratic and cubic) and linear models were built to predict the percentage change in population per 10 years intervals. Each of the models is illustrated in the following graphs (Figure 10, exponential, Figure 11, quadratic, Figure 12, cubic and Figure 13, linear).

The polynomial second order (quadratic) model for predicting the change in \% change in population $/ 10$ years versus years is given as, $y=0.0107 x^{2}-$ $44.019 x+45360$. The coefficient of correlation $R^{2}$ is $90 \%$. Hence, the model explains $90 \%$ of the variability in the population data.

The cubic model is given as, $y=-0.0009 x^{3}+5.6547 x^{2}-11272 x+7000000$, with $R^{2}=0.9235$.

The exponential model is represented by the following equation.

$y=3 \mathrm{E}+20 \mathrm{e}^{-0.022 x}=0$, with $R^{2}=0.9264$. It explains almost $93 \%$ of the variation in the population data.

The linear model for \% change in population is given by the following equation, $y=-1.5076 x+3073.7$

Table 11. \% Change in population for 10-year intervals.

\begin{tabular}{cc}
\hline Year & \% Change in population/10 years interval \\
\hline $1950-1960$ & 134.4615 \\
$1960-1970$ & 85.5643 \\
$1970-1980$ & 81.89533 \\
$1980-1990$ & 85.22551 \\
$1990-2000$ & 52.83375 \\
$2000-2010$ & 43.40063 \\
$2010-2019$ & 33.16732 \\
\hline
\end{tabular}

\section{$\%$ Change in population/10 years}

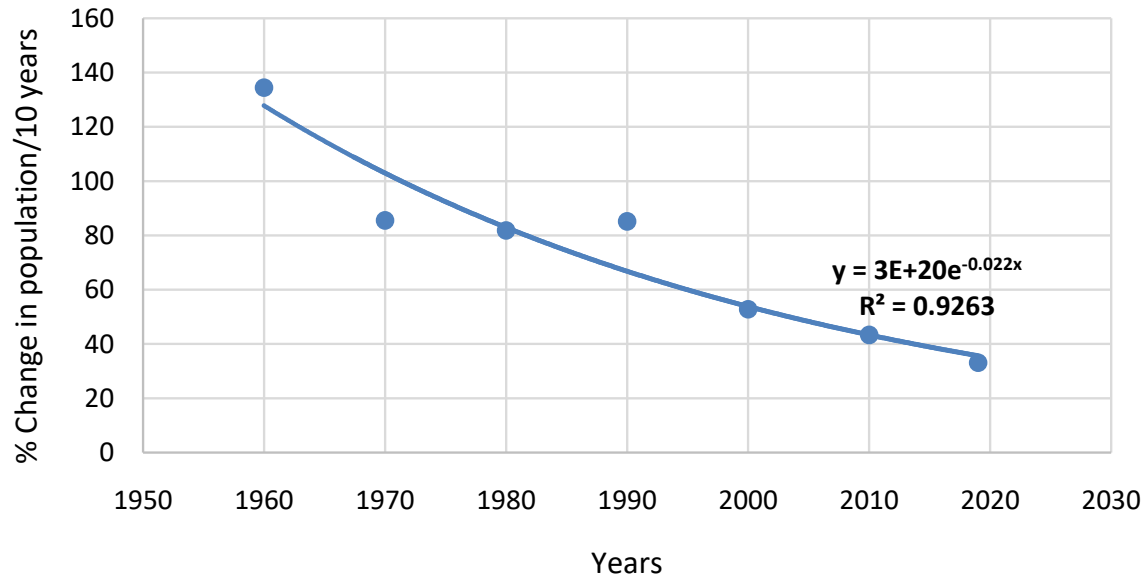

Figure 10. Percentage change in population/10 years versus years (exponential model). 
$\%$ Change in population/10 years interval versus years (quadratic model)

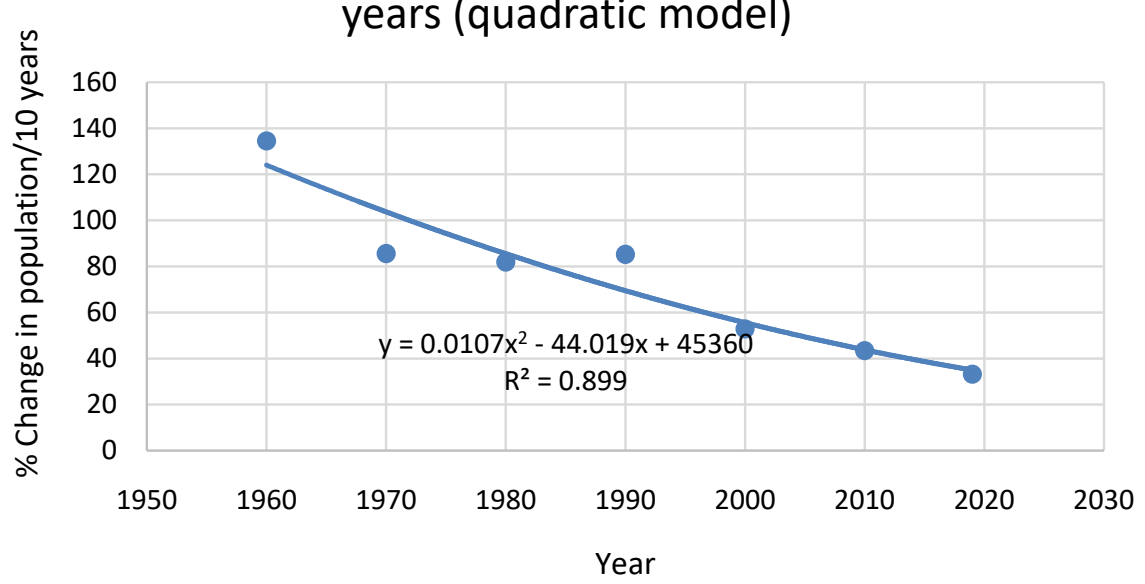

Figure 11. Percentage change in population/10 years versus years (quadratic model).

\section{$\%$ of change in population/10 years interval} versus years (cubic model)

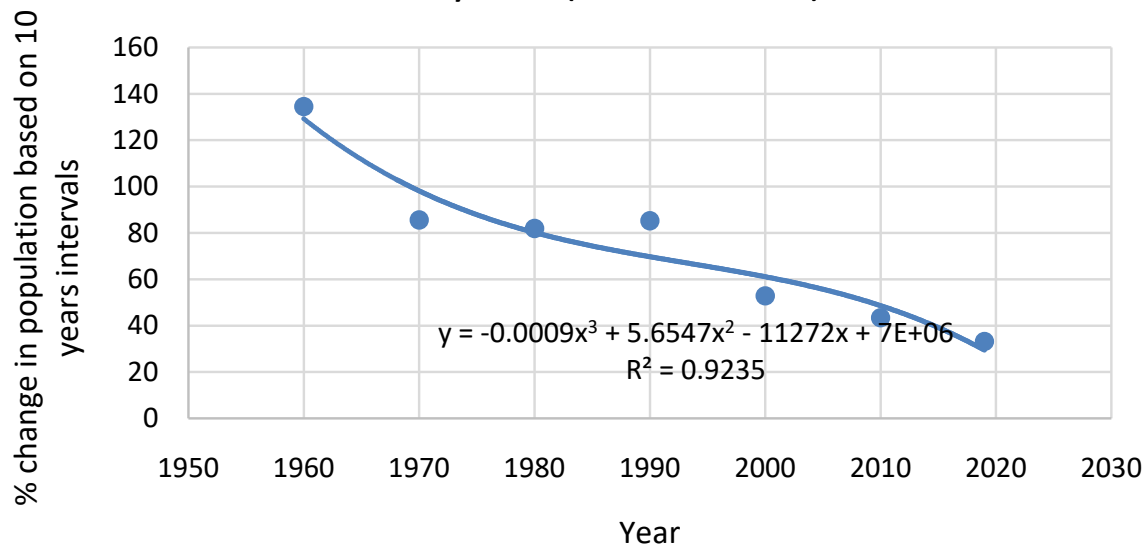

Figure 12. Percentage change in population/10 years versus years (cubic model).

\section{$\%$ Change in population/10 years interval versus years (linear model)}

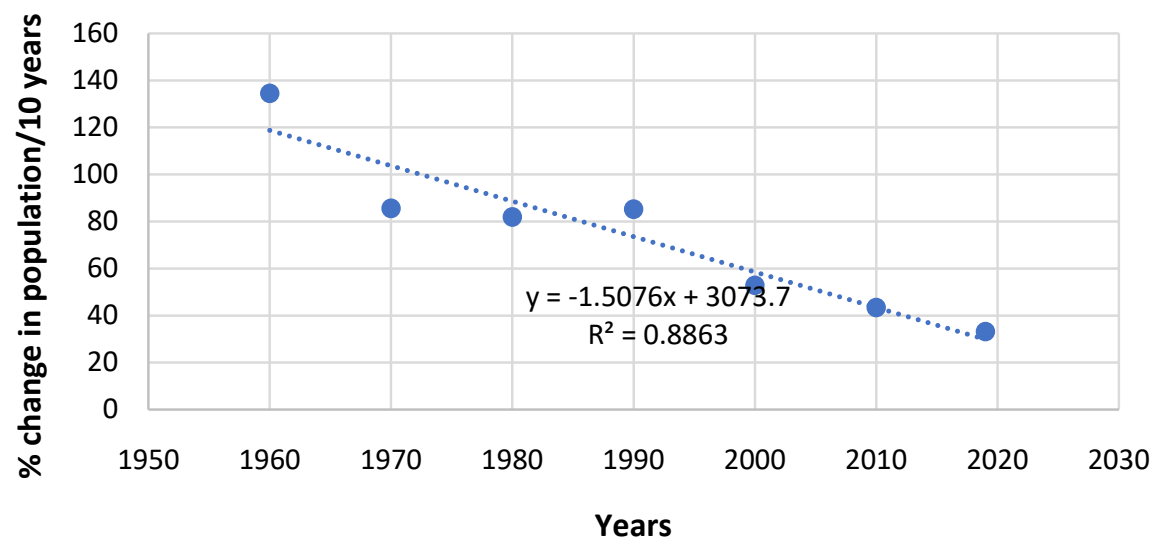

Figure 13. Percentage change in population/10 years versus years (linear model). 
To predict the year when the population of Lagos city would stabilize y was equated to 0 and an attempt to solve for $x$ in each model made.

Hence, for the exponential model, $y=3 \mathrm{E}+20 \mathrm{e}^{-0.022 x}=0$

The equation is solved by subtracting 3000 from the left-hand and right-hand sides simultaneously, $20 \mathrm{e}^{-0.022 x}=-3000$.

Dividing the left-hand side and right-hand side by 20 and getting the natural logarithms of both sides yields the following.

$$
-0.022 x=\ln (-3000 / 20)
$$

Dividing both sides by -0.022 .

Hence, $x=\ln (150) /-0.022$, which has no solution.

Both the quadratic and cubic models offer no feasible solutions for predicting the year for population stabilization since they either have complex or real solutions falling outside future time (years). Hence, they cannot be used to predict the year of population stabilization for the given data. The best model was the linear model (Figure 13). The year for stabilization of population is computed from the linear model for $\%$ change in population as follows. The linear model is equated to 0 and then solved as follows:

$$
\begin{gathered}
y=-1.5076 x+3073.7=0 \\
-1.5076 x=-3073.7 \\
x=(-3073.7 /-1.5076) \\
x=2038.8034
\end{gathered}
$$

Hence, the population is expected to stabilize during the time span 2029-2039. The population corresponding to the year 2039 was estimated by extrapolating the polynomial model illustrated in Figure 8 to the year 2039, using the format trendline option of Microsoft Excel. The resulting graph is illustrated in Figure 14. According to Figure 14, in 2039 the population of Lagos city will be $23,000,000$, the stabilization population.

Projected population of Lagos City for 2050-2039 versus year with projection (quadratic model)

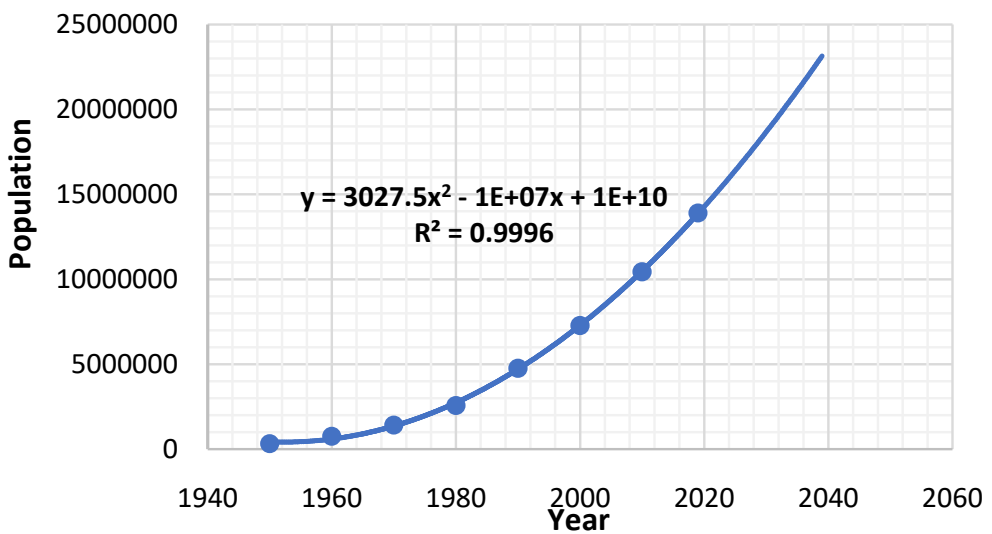

Figure 14. Projected population for the period 1950-2039, using a polynomial second order model for Lagos City Population versus year based on 1950, 1960, 1970, 1980, 1990, 2000, 2010 and 2019 data. 
The rate of change of population/year based on 10 years intervals rose linearly with respect to time (years) as illustrated in Figure 10. The lowest population growth/year was shown to have occurred during the time span 1950-1960. Interestingly, the highest \% change in population occurred also during this time span (see Table 11). This is the only time span found to have a $\%$ change in population above $100 \%$.

The percentage increase in the city's population was found to be decreasing linearly with respect to time, in years (Figure 10). However, the city's population still rose since the percentage increase was still greater than $0 \%$. The population is expected to stabilize when the percentage change drops to $0 \%$. According to Abiodun (1974), between 1952 and 1963, the population of Agege and Ikorodu, sections of Lagos metropolitan area increased by $300 \%$ and $1000 \%$ respectively. The high percentage growth can be explained by a three-fold introduction of babies into Lagos by families immigrating into the city, for every baby born to residents (Abrams et al., 1980). This explains the high \% increase in population during 1950-1960.

A factor that may influence the stabilization of a city's population is its urban carrying capacity. This refers to the maximum population able to survive in an urban environment, considering all other factors impacting the city's services and resources for sustainable development [27] [28]. A city's population is influenced by several factors. Among them are, space for construction of residential structure, design of city, shape of structures, capacity of structures, structural strength of structures, land cove/land use, land slope, hydrology of the city, climate, weather. Others are, politics quality of life, etc. These factors determine the sustainability and carrying capacity of a city. Some of the listed factors are fixed while others are dynamic. Although the model for population growth suggests continual increase with respect to time (years), the population of Lagos like other cities has a limit. The limit is reached when \% change stops (equal to zero). According to this study, stabilization is expected when the population reaches $23,000,000$. However, the number could be higher if factors affecting its carrying capacity favor the city to hold more residents sustainably.

\section{Policy Recommendations and Conclusion}

The rapid urbanization rate in the area not only created unprecedented consequences by diminishing the quality of the environment but it raised serious implications for land management in the region. Provision of green planning education for city managers, developers, and the public in the state is required. This would go a long way in raising awareness about the dangers of initiating future developments in areas deemed adjacent to sensitive natural habitats known for their ecological services for communities while familiarizing them of the risks of encroaching on ecologically fragile areas. There is also the need for use of information technologies in land administration. Although Nigeria has its own space administration with the goal of providing needed data in land management, the 
land administration has several challenges in use of information technologies such as multiples problems arising from lack of spatial information tools and infrastructure, inadequate training and lack of coordination between agencies [15] [17]. Use of information technogies will go a long way in helping sustainability and management of land resources.

\section{Conflicts of Interest}

The authors declare no conflicts of interest regarding the publication of this paper.

\section{References}

[1] Vargas-Hernández, J.G., Pallagst, K. and Zdunek-Wielgołaska, J. (2018) Urban Green Spaces as a Component of an Ecosystem. In: Dhiman, S. and Marques, J., Eds., Handbook of Engaged Sustainability, Springer, Cham, 1-32.

https://doi.org/10.1007/978-3-319-53121-2 49-1

[2] World Health Organization (2019) Health and Sustainable Development: Urban Green Spaces.

https://www.who.int/sustainable-development/cities/health-risks/urban-green-spac e/en

[3] Torrey, B.B. (2004) Urbanization: An Environmental Force to Be Reckoned with. Population Reference Bureau (PRB).

https://www.prb.org/urbanization-an-environmental-force-to-be-reckoned-with

[4] Alberti, M. (2005) The Effects of Urban Patterns on Ecosystem Function. International Regional Science Review, 28, 168-192. https://doi.org/10.1177/0160017605275160

[5] Güneralp, B. and Seto, K.C. (2008) Environmental Impacts of Urban Growth from an Integrated Dynamic Perspective: A Case Study of Shenzhen, South China. Global Environmental Change, 18, 720-735. https://doi.org/10.1016/j.gloenvcha.2008.07.004

[6] Li, J., Deng, X.Z. and Seto, K.C. (2013) The Impact of Urban Expansion on Agricultural Land Use Intensity in China. Land Use Policy, 35, 33-39. https://doi.org/10.1016/j.landusepol.2013.04.011

[7] Merem, E.C. and Twumasi, Y.A. (2005) GIS Based Analysis of Growth Management and Environmental Decline in Central Mississippi Region. Geographic Information Sciences, 11, 130-138. https://doi.org/10.1080/10824000509480608

[8] Condon, P.M., Mullinix, K., Fallick, A. and Harcourt, M. (2010) Agriculture on the Edge: Strategies to Abate Urban Encroachment onto Agricultural Lands by Promoting Viable Human-Scale Agriculture as an Integral Element of Urbanization. International Journal of Agricultural Sustainability, 8, 104-115. https://doi.org/10.3763/ijas.2009.0465

[9] Curran-Cournane, F., Vaughan, M., Memon, A. and Fredrickson, C. (2014) Trade-Offs between High Class Land and Development: Recent and Future Pressures on Auckland's Valuable Soil Resources. Land Use Policy, 39, 146-154. https://doi.org/10.1016/j.landusepol.2014.02.020

[10] Curran-Cournane, F., Cain, T., Greenhalgh, S. and Samarsinghe, O. (2016) Attitudes of a Farming Community towards Urban Growth and Rural Fragmentation-An Auckland Case Study. Land Use Policy, 58, 241-250. 
https://doi.org/10.1016/j.landusepol.2016.07.031

[11] Twumasi, Y.A., Coleman, T.L. and Manu, A. (2003) Monitoring of Urban Growth in the Accra Metropolitan Area, Ghana Using Satellite Imagery. The Journal of the Alabama Academy of Science, 74, 95.

[12] Twumasi, Y.A., Manu, A. and Coleman, T.L. (2004) Monitoring Urban Expansion of Bamako, Mali, Using Principal Component Analysis of Multi-Temporal Landsat Data. The Journal of the Alabama Academy of Science, 75, 81.

[13] Manu, A., Twumasi, Y.A., Kang, S.L. and Coleman, T.L. (2015) Predicting Urban Growth of a Developing Country City Using a Statistical Modeling Approach. International Journal of Geomatics and Geosciences, 5, 603-613.

[14] Adeonipekun, P.A., Oyetola Olusegun Oyebanji, O.O. and Adebayo, M.B. (2019). Impact of Seasonal Changes on the Vegetation Composition of Some Selected Areas in Lagos State, Nigeria. Mediterranean Botany, 40, 53-70.

[15] Merem, E.C., Twumasi, Y.A., Wesley, J., Isokpehi, P., Fageir, S., Crisler, M., Romorno, C., Hines, A., Ochai, G.S., Leggett, S. and Nwagboso, E. (2018) Analyzing Emerging Environmental Issues in Major Areas: The Case of Lagos in South West Nigeria. Architecture Research, 8, 19-38. https://doi.org/10.5923/j.arch.20180801.03

[16] Smith, R. (2019) A Heavily Crowded Street in Lagos, Nigeria. https://www.reddit.com/r/UrbanHell/comments/ayr4m7/a heavily crowded street in lagos nigeria

[17] Osei, A., Merem, E.C. and Twumasi, Y.A. (2006) Use of GIS and Remote Sensing Technology as a Decision Support Tool in Land Administration: The Case of Lagos, Nigeria. Proceedings of the 5 th International Federation of Surveyors (FIG) Regional Conference for Africa, Accra, 8-11 March 2006, 1-18.

http://www.fig.net/resources/proceedings/fig proceedings/accra/techprog.htm

[18] Olaleye, J.B., Abiodun, O.E. and Igbokwe, Q. (2019) Land Use Change Detection and Analysis Using Remotely Sensed Data in Lekki Peninsula Area of Lagos, Nigeria. The Proceedings of the International Federation of Surveyors (FIG) Regional Conference, Eilat, 3-8 May 2009, 1-15.

https://fig.net/resources/proceedings/fig proceedings/fig2009/papers/ts08b/ts08b o laleye etal 3493.pdf

[19] Obiefuna, J.N., Nwilo, P.C., Atagbaza, A.O. and Okolie, C.J. (2013) Land Cover Dynamics Associated with the Spatial Changes in the Wetlands of Lagos/Lekki Lagoon System of Lagos, Nigeria. Journal of Coastal Research, 288, 671-679. https://doi.org/10.2112/JCOASTRES-D-12-00038.1

[20] Makinde, E.O. and Oyelade, O. (2018) Land Cover Mapping Using Sentinel-1 SAR Satellite Imagery of Lagos State for 2017. Conference: Economy, Sustainable Development and Energy International Conference, Edinburgh, 25-27 June 2018, 1399. https://doi.org/10.3390/proceedings2221399

[21] Adegboyega, S.A., Oloukoi, J., Olajuyigbe, A.E. and Ajibade, O.E. (2019) Evaluation of Unsustainable Land Use/Land Cover Change on Ecosystem Services in Coastal Area of Lagos State, Nigeria. Applied Geomatics, 11, 97-110. https://doi.org/10.1007/s12518-018-0242-2

[22] Population Stat: World Statistical Data (2019) Lagos, Nigeria Population. https://populationstat.com/nigeria/lagos

[23] Google (2020) Google Map for Location of Lagos. https://www.google.com/maps/place/Lagos,+Nigeria/@6.5479775,3.0037633,10z/dat a=!4m5!3m4!1s0x103b8b2ae68280c1:0xdc9e87a367c3d9cb!8m2!3d6.5243793!4d3.37 $\underline{92057}$ 
[24] U.S. Geological Survey (2019) Landsat Data: U.S. Geological Survey Database. https://earthexplorer.usgs.gov

[25] Horning, N. (2010) Random Forests: An Algorithm for Image Classification and Generation of Continuous Fields Data Sets. Proceedings of the International Conference on Geoinformatics for Spatial Infrastructure Development in Earth and Allied Sciences, Osaka, Vol. 911, 1-6.

[26] Li, L., Zhang, L., Wang, H., Wang, J., Yang, J., Jiang, D., Li, J. and Qin, A.D. (2007) Assessing the Impact of Climate Variability and Human Activities on Stream Flow from the Wuding River Basin in China. Hydrological Processes, 21, 3485-3491. https://doi.org/10.1002/hyp.6485

[27] Wei, Y., Huang, C., Lam, P., Sha, Y. and Feng, Y. (2015) Using Urban-Carrying Capacity as a Benchmark for Sustainable Urban Development: An Empirical Study of Beijing. Sustainability, 7, 3244-3268. https://doi.org/10.3390/su7033244

[28] Tian, Y. and Sun, C. (2018) Comprehensive Carrying Capacity, Economic Growth and the Sustainable Development of Urban Areas: A Case Study of the Yangtze River Economic Belt. Journal of Cleaner Production, 195, 486-496. https://doi.org/10.1016/j.jclepro.2018.05.262 